\title{
OTOMASI REAL TIME SYSTEM TESTER EQUIPMENT OVERALL EQUIPMENT EFFECTIVENESS DI PT. ABC
}

\author{
Missyamsu Algusri \\ Dosen Tetap Prodi Teknik Elektro, Fakultas Teknik, Universitas Riau Kepulauan
}

\begin{abstract}
ABSTRAKSI
Sebuah pabrik tanpa sebuah tampilan unjuk kerja seperti sebuah mobil yang tidak mempunyai speedometer. Anda mungkin mengerti kemana akan pergi tetapi anda tidak akan tahu kapan sampai ke tujuan. Otomasi akuisisi data dilakukan untuk membangun sistem informasi manufaktur dengan cara mengambil kondisi tester status yang diadopsi dari faktor six big looses di dalam konsep OEE. Komputerisasi memungkinkan penampilan waktu nyata proses produksi, detail kinerja elemen produksi, penelusuran status equipment, dan sistem peringatan untuk equipment major down. Metode RAD dipilih untuk pengembangan karena lingkup yang tidak terlalu besar tetapi rentang waktu singkat dengan keunggulan pengakomodasian keinginan pemakai dengan proses pengulangan untuk penyempurnaan. Sistem OEE terotomasi yang menggantikan sistem manual dapat meningkatkan kualitas informasi, akses instan ke informasi produksi memungkinkan supervisor atau engineer memonitor kinerja sistem produksi dan bereaksi dengan cepat dan tepat telah meningkatkan produktifitas yang diukur dari cycle time produk.
\end{abstract}

Kata Kunci : Otomasi, OEE, Komputerisasi

\section{PENDAHULUAN}

\subsection{Latar Belakang}

Penggunaan sistem informasi di dalam industri manufaktur atau sistem informasi manufaktur merupakan salah satu solusi penting bagi perusahaan di dalam upaya peningkatan efektifitas dan efisiensi sumber daya yang ada untuk mencapai hasil yang optimum. Salah satu hasil penggunaan sistem informasi manufaktur adalah pengurangan looses yang tidak diperlukan di dalam proses produksi.

Salah satu metode pengukuran kinerja proses manufaktur dalam industri yang banyak digunakan adalah equipment performance atau overall equipment effectiveness (OEE) yang memperlihatkan efektifitas mesin di dalam proses produksi. Di beberapa perusahaan $O E E$ dipergunakan sebagai fundamental KPI ( Key Performance Indicator) untuk pengukuran kinerja mesin dan juga pembanding level produktifitas perusahaan terhadap industri standar umumnya. OEE dihitung dengan mengambil informasi kondisi equipment availability, performance rate dan quality rate.

Sistem informasi manufaktur OEE yang berkualitas harus dibangun dari data proses produksi yang berkualitas juga. Faktor kualitas informasi yang sangat diperlukan untuk membangun sistem OEE adalah ketersediaan (timelines), up to date (currency) dan akurat (accuracy). Ketersediaan data mutlak diperlukan untuk membangun sistem OEE yang menampilkan proses produksi secara real time.

Beberapa perusahaan mengumpulan data-data proses produksi dilakukan secara manual dengan mencatat ke dalam selembar form. Kekurangan metode ini antara lain errors yang mungkin terjadi, time factor atau selisih antara waktu kejadian dengan waktu ketika data diakses, menimbulkan labor cost yang besar dan terjadinya deviasi-deviasi data baik yang disengaja maupun yang tidak disengaja. Otomasi akuisisi data dengan cara memonitor aktifitas equipment dapat mengurangi kesalahan-kesalahan tersebut. Saat ini beberapa jenis equipment 
telah dilengkapi fasilitas otomasi sistem monitoring dari pabriknya yang memungkinkan output berupa file komputer yang dapat diolah sesuai kebutuhan dan memungkinkan ditampilkan secara real-time.

Teknologi sistem waktu - nyata (real - time system) begitu pesat berkembang dan aplikasinya telah meluas di berbagai bidang. Mesin ATM (Automatic Teller Machine) bank, sistem informasi saham, pemesanan tiket pesawat terbang, Live streaming di televisi dan komunikasi video adalah beberapa contohnya. Applikasi teknologi real time dalam industri manufaktur memungkinkan penampilan gambaran dari sebuah proses produksi, gambaran yang dimaksud adalah representasi kondisi dari sebuah proses produksi. Keseluruhan proses ini dapat mencakup real time equipment monitoring capabilities untuk product output quantity, kondisi mesin real time status dan historical state. Instan akses ke informasi real time proses produksi memungkinkan supervisor atau engineer membandingkan kinerja antara line produksi dan bereaksi terhadap abnormalitas dengan cepat dan akurat.

Data historical state lot-lot yang ditest dari bulan januari 2011 sampai bulan april 2011 yang diambil dari intranet PT. ABC menunjukkan terjadinya deviasi antara aktual lot cycle time dibandingkan target lot cycle time sebesar 53,9\%. Untuk mengetahui alasan tidak tercapainya target tersebut perlu dianalisa data proses produksi, baik itu data berupa downtime mesin, kondisi operator maupun data-data lainnya. Saat diakses data-data produksi yang diupload, ditemukan $10 \%$ data tidak terupdate karena form hilang atau terlewati proses scanning. Analisa data proses produksi seperti yang terlihat di lampiran 1 sangat sulit dilakukan karena harus dilakukan secara manual dan juga banyak ditemukan data tidak akurat.

Sistem informasi manufaktur tester overall equipment effectiveness menghasilkan tracking mesin reability dan maintainability yang lebih baik sehingga akan meningkatkan efektifitas, utilisasi mesin dan produktifitas perusahaan yang ditunjukkan lot cycle time yang optimal dengan biaya murah.

\subsection{Rumusan Masalah}

Perumusan masalah dalam penelitian ini adalah bagaimana rekayasa sistem informasi manufaktur tester overall equipment effectiveness yang dapat memonitor proses produksi dengan cara penampilkan proses produksi secara real time dan tracking equipment status.

\subsection{Tujuan Penelitian}

Tujuan penelitian ini adalah

1. Mengidentifikasi dan menganalisis permasalahan sistem informasi manufaktur equipment monitoring system yang ada saat ini di PT. ABC dan kebutuhan sistem baru yang diharapkan sebagai solusi.

2. Mendesain sistem informasi manufaktur tester overall equipment effectiveness yang dapat memonitor proses produksi.

3. Membangun sistem informasi manufaktur tester overall equipment effectiveness yang dapat memonitor proses produksi.

\section{KAJIAN LITERATUR}

\subsection{Sistem Informasi}

Informasi ibarat darah yang mengalir di dalam tubuh suatu organisasi, sehingga informasi ini sangat penting di dalam suatu organisasi. Suatu sistem yang kurang mendapatkan informasi 
akan menjadi luruh, kerdil dan akhirnya berakhir. Anthony dan Dearden (1980) menyebut keadaan dari sistem hubungannya dengan keberakhiran dengan istilah entropy.

Menurut John Burch dan Gary Grudnitski (1986) kualitas dari informasi ditunjang oleh tiga pilar yaitu akurat (accurate), tepat pada waktunya (timeliness) dan relevan (relevance). Menurut O’Brien (2003) dalam bukunya System Analysis and Design Method kualitas informasi terlihat dari 3 dimensi yaitu ;

1. Dimensi waktu ( time dimension), informasi yang ada saat ini harus ;

a. Informasi tersedia saat diperlukan (timelines).

b. Informasi tersedia dalam frekuensi tertentu (frequency).

c. Informasi up to date (currency).

2. Dimensi isi (content dimension);

a. Tidak terdapat kesalahan informasi atau akurat (accuracy).

b. Informasi sesuai dengan kebutuhan (relevance).

c. Informasi yang disajikan diperlukan oleh pemakai (conciseness).

d. Informasi dapat menunjukkan kinerja dengan mengukur aktivitas yang diselesaikan, kemajuan yang dicapai, atau sumber daya yang diakumulasi (performance).

3. Dimensi bentuk (form dimension)

a. Bentuk informasi sesuai dengan harapan customer dan dalam bentuk yang mudah digunakan (media) dan mudah dipahami (presentation).

b. Informasi harus tersedia dalam bentuk yang mudah dipahami, jelas, rinci dan berurutan.

\subsubsection{Sistem Informasi Manufaktur}

Sistem Informasi Manufaktur (SIMa) termasuk dalam kerangka kerja Sistem Informasi Manajemen (SIM) secara keseluruhan. SIMa lebih menekankan kepada proses produksi yang terjadi dalam sebuah lantai produksi, mulai dari input bahan mentah hingga output barang jadi, dengan mempertimbangkan semua proses yang terjadi.

\subsection{Otomasi dan CIM Dalam Industri Manufaktur}

Groover (2005) mendefinikan otomasi sebagai suatu teknologi yang terkait dengan masalah penerapan sistem mekanik, elektronika dan sistem berbasis komputer dengan tujuan pengoperasian dan pengendalian suatu sistem produksi.

\subsubsection{Sistem Manufaktur Terotomasi}

Elemen yang terotomasi dapat dibagi 2 kategori yaitu sistem manufaktur terotomasi pada lantai produksi dan sistem penunjang manufaktur berbasis komputer. Dalam sistem produksi modern kedua kategori tersebut mempunyai area yang saling tumpang tindih, karena sistem manufaktur terotomasi yang berjalan pada lantai produksi itu sendiri sering diterapkan dengan sistem komputer dan dihubungkan dengan penunjang manufaktur yang terkomputerisasi serta sistem informasi manajemen pada tingkat pabrik dan perusahaan. Istilah sistem manufaktur terintegrasi berbasis komputer ( CIM ) digunakan untuk menunjukkan pemamfaatan secara mendalam dari komputer dalam sistem produksi.

\subsubsection{Sistem Penunjang Manufaktur Terkomputerasi}

Otomasi dari sistem manufaktur bertujuan untuk mengurangi usaha yang harus dilakukan secara manual atau secara kasar dalam bidang perancangan produk, perencanaan dan pengendalian manufaktur serta fungsi-fungsi usaha dalam suatu perusahaan.

Hampir semua sistem penunjang manufaktur modern diimplemantasikan memakai komputer. Tentu saja teknologi komputer juga digunakan untuk mengimplementasikan otomasi manufaktur di suatu pabrik. Istilah sistem manufaktur terintegrasi berbasis komputer (CIM) menandai penggunaan komputer secara luas dan intensif untuk merancang produk, merencanakan produksi, mengendalikan operasi, dan melaksanakan fungsi-fungsi usaha terkait yang dibutuhkan perusahaan. 


\subsubsection{Tenaga Kerja Manual dalam Sistem Produksi}

Dalam sistem manufaktur yang mempunyai otomasi tinggi, tenaga manusia masih tetap merupakan komponen yang dibutuhkan dalam sebuah perusahaan. Tenaga manusia dapat dibedakan menjadi 2 kategori yaitu tenaga kerja dalam operasi manufaktur dan tenaga kerja manusia dalam sistem penunjang manufaktur.

\subsection{Pengembangan Sistem Informasi Manajemen}

Pengembangan sistem (systems development) dapat berarti menyusun suatu sistem yang baru untuk menggantikan sistem yang lama secara keseluruhan atau memperbaiki sistem yang telah ada. Pengembangan sistem diperlukan dalam beberapa keadaan seperti (a). Adanya permasalahan-permasalahan (problem) yang timbul di sistem lama yaitu ketidakberesan sehingga sistem lama tidak beroperasi sesuai dengan yang diharapkan dan pertumbuhan organisasi; (b). Untuk meraih kesempatan-kesempatan (opportunities) seperti memenangkan persaingan bisnis dan (c). Adanya instruksi-instruksi (directives) baik dari atasan maupun dari peraturan pemerintah.

Dengan dikembangkannya sistem yang baru, maka diharapkan akan terjadi peningkatan-peningkatan di sistem yang baru. Peningkatan-peningkatan ini berhubungan dengan PIECES yaitu singkatan dari Performance(kinerja), Kualitas informasi, Ekonomi, Control (pengendalian) dalam mendeteksi dan memperbaiki kesalahan dan kecurangan, Efisiensi dan Services (pelayanan), Jogiyanto (2005).

\subsection{Pengembangan Sistem Informasi Manufaktur}

Pengembangan Sistem informasi di dalam industri manufaktur atau sistem informasi manufaktur telah banyak digunakan perusahaan untuk meningkatkan produktifitas. Salah satunya adalah CIM yang diapplikasikan untuk merancang produk, merencanakan produksi, mengendalikan operasi, dan melaksanakan fungsi-fungsi usaha terkait yang dibutuhkan perusahaan.

\subsubsection{Overall Equipment Effectiveness}

Pemamfaatan sistem informasi untuk sistem produksi khususnya bagian penunjang manufaktur salah satunya adalah sistem informasi manufaktur overall equipment effectiveness yang termasuk di dalam applikasi CIM. Konsep OEE pertama kali diperkenalkan oleh TAKAJIMA(1998) sebagai salah satu pendekatan untuk mengevaluasi proses yang dicapai melalui inisiatif peningkatan sebagai salah satu bagian dari filosofi Total Productive Maintenance (TPM).

\subsubsection{OEE sebagai Ukuran Kinerja.}

Pengukuran kinerja didefinisikan sebagai proses kuantifikasi tingkat efisiensi dan efektifitas suatu aktivitas kedalam nilai yang terukur (Neely,1995). Dari perspektif manajemen, pengukuran kinerja memiliki beberapa tujuan antara lain ; a) untuk menyediakan informasi umpan balik yang sangat berguna untuk kemajuan perusahaan, b) untuk mendiagnosa suatu masalah, c) untuk menilai tingkat efektivitas strategi yang dipakai dan d) untuk mengidentifikasikan kesuksesan dan peluangnya di masa yang akan datang.

Ukuran kinerja mesin atau overall equipment effectiveness memperlihatkan efektifitas mesin di dalam memproduksi produk. OEE dibuat dengan mengambil informasi kondisi equipment availability, performance rate dan quality rate. Di beberapa perusahaan, OEE dipergunakan sebagai fundamental KPI ( Key Performance Indicator ) untuk pengukuran kinerja mesin dan juga pembanding level produktifitas perusahaan terhadap industri standar .

\subsubsection{Otomasi dan Visual OEE}

Pernahkah anda mengendarai sebuah mobil dengan speedometer tidak bekerja ? bayangkan sejenak bahwa anda tidak dapat mengatakan berapa cepat atau berapa lambat anda bergerak. Sebuah perusahaan tanpa sebuah display dari ukuran kinerja seperti sebuah mobil yang tidak mempunyai speedometer. Anda mungkin mengerti kemana akan pergi tetapi anda tidak akan dapat mengatakan kapan anda sampai ke tujuan. 
Real-time display merupakan penampilan proses produksi yang memungkinkan operator dan maintenance personal anda untuk merespon cepat masalah-masalah yang mengganggu dan mengurangi produktifitas perusahaan. Visualiasi proses dapat melayani seperti sebuah meteran yang membuat anda dapat menentukan kapan membuat perubahan dengan improvement dan juga memberikan data secara real time.

Pengambilan data otomatis ( Automatic data capture - ADC ) yang juga dikenal dengan pengambilan dan pengidentifikasian otomatis (automatic identification and data capture AIDC ), mengacu pada teknologi yang menyediakan pemasukan data ke dalam komputer atau sistem lain yang dikendalikan pemroses mikro tanpa menggunakan keyboard. Banyak dari teknologi ini yang tidak memerlukan keterlibatan manusia dalam pengambilan data dan proses pemasukan.

Sistem pengidentifikasian otomatis digunakan semakin banyak untuk mengumpulkan data dalam applikasi penanganan material dan untuk manufaktur. Dalam penangan material, penerapan ini meliputi pengiriman dan penerimaan, penyimpanan, penyortiran, pengambilan pesanan, penyiapan gabungan part untuk perakitan.

\subsection{Perusahaan Manufaktur Semikonduktor}

PT. ABC adalah perusahaan semikonduktor bertaraf multinasional yang mempunyai luas wilayah worldwide $34.375 \mathrm{~m} 2$ melayani servis berupa wafer probe, wafer backgrinding, assembly dan final test komponen semikonduktor IC.

\subsubsection{Pengetesan Elektrikal Integrated Circuit}

Salah satu layanan dan divisi dari PT. ABC adalah final test yaitu proses pengetesan fungsi elektrikal komponen IC. Dengan menggunakan mesin utama yang disebut tester dibantu mesin handler yang mengatur pergerakan komponen IC secara otomatis maka setiap IC yang diproduksi akan ditest fungsi elektrikalnya dan secara otomatis akan dipisahkan oleh mesin handler antara yang memenuhi spesifikasi yang ditentukan sebagai good unit dan yang tidak memenuhi spesifikasi sebagai reject unit.

\subsubsection{Cycle Time}

IC cycle time adalah waktu yang dibutuhkan untuk satu proses pengetesan unit IC yang disebut test time. Untuk beberapa device yang di test secara paralel maka test time dihitung dari banyaknya jumlah site. Karena jumlah produksi IC yang banyak biasanya perhitungan output berdasarkan hitungan kuantitas 1 lot, sehingga untuk cycle time hitungan yang dipakai adalah lot cycle time. Test time di PT. ABC dapat dilihat di lampiran.

Lot cycle time merupakan salah satu indikator faktor-faktor OEE. Semakin singkat waktu pengerjaan sebuah production lot maka semakin baik pencapaian utility, speed dan quality proses produksi yang ditunjukkan dari nilai pencapaian OEE dalam persen.

\subsection{Metodelogi Pengembangan SIM}

Konsep siklus hidup cocok dengan segala sesuatu yang lahir, tumbuh berkembang menjadi matang dan akhirnya mati, pola ini juga berlaku untuk sistem informasi manajemen. Metodologi pengembangan SIM polanya lebih dipengaruhi oleh kebutuhan untuk mengembangkan sistem yang lebih cepat. Pengembangan SIM yang lebih responsif dapat dicapai dengan dengan peningkatan siklus hidup dan penggunaan peralatan pengembangan yang berbasis komputer (computer-based development tool). Dua contoh metodologi peningkatan yang populer adalah prototyping dan rapid application development $(R A D)$.

\section{KERANGKA KONSEP PENELITIAN}

\subsection{Kerangka Konsep}

Menghasilkan sistem informasi manufaktur yang berkualitas dengan akuisisi data yang juga berkualitas. Terjadinya deviasi-deviasi data karena proses manual akan dikurangi dengan menggantikan sistem akuisisi data menjadi terotomati. Otomasi dilakukan dengan membuat program untuk mendeteksi aktifitas tester dan handler. 


\subsection{Lot Cycle Time Sebagai Indikator}

Lot cycle time merupakan salah satu indikator faktor-faktor OEE. Semakin singkat waktu pengerjaan sebuah production lot maka semakin baik pencapaian utility, speed dan kualitas proses produksi yang ditunjukkan dari nilai pencapaian OEE dalam persen

\section{METODE PENELITIAN}

\subsection{Metode Penelitian}

Mempertimbangkan waktu dan proyek yang tidak begitu besar maka metodologi pengembangan sistem yang dipilih adalah rapid application development (RAD) dengan penyesuaian sesuai kebutuhan. Evaluasi dilakukan dengan mempertimbangkan aspek PIECES.

\section{PENGUMPULAN DATA DAN ANALISIS SISTEM}

\subsection{Requirement Planning}

Permasalahan dianalisa dari proses bisnis yang diterapkan oleh perusahaan saat ini, tujuan utama dari analisis proses bisnis adalah untuk mempelajari alur yang ada di dalam perusahaan yang terjadi sehari-hari. Proses bisnis yang berlangsung di PT. ABC dalam akuisisi data proses produksi dapat dilihat pada gambar 1.

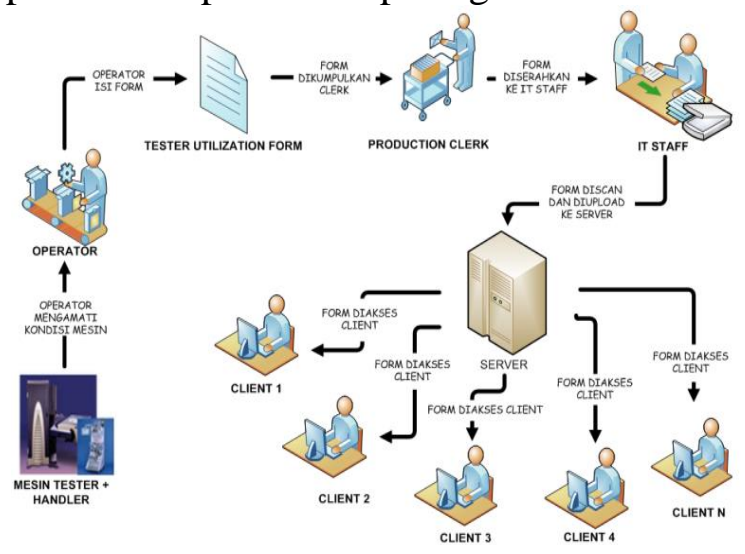

Gambar 1. Proses bisnis akuisisi data proses produksi

\subsection{Define Requirement.}

Hasil final sistem yang diinginkan, sistem tersebut berupa ; a) Real time equipment monitoring, b) Historical equipment status, c) OEE reporting dan d) Sistem alert untuk equipment yang down lebih dari 3 jam.

Keinginan-keinginan user yang telah diidentifikasi tidak mungkin dapat diterapkan dengan sistem akuisisi data secara manual yang dilakukan saat ini, sehingga perlu dirancang sistem otomasi akuisisi data yang terkomputerisasi.

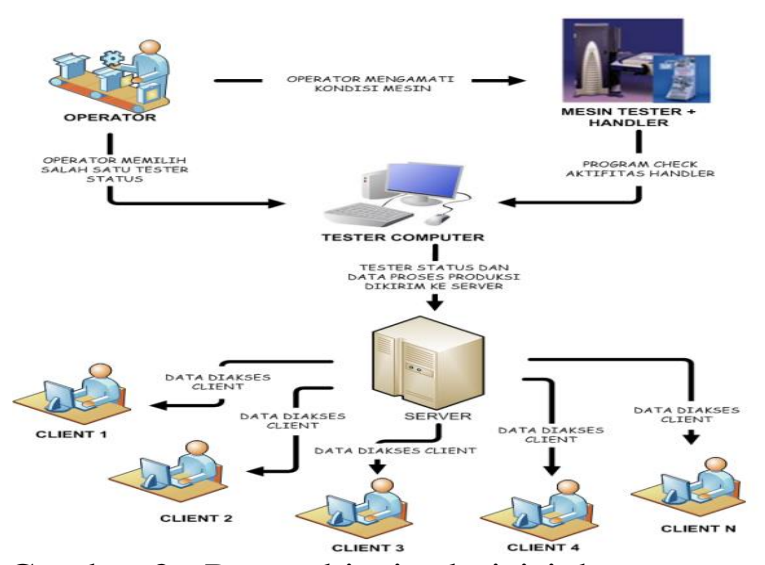

Gambar 2. Proses bisnis akuisisi data terotomasi

\subsubsection{Identifikasi Tester Status}

Perhitungan OEE dilakukan dengan cara menghitung persentase dari tester status. Implementasi equipment status diadopsi dari six big looses dalam teori OEE, six big looses 
tersebut adalah a) equipment failure, b) setup and adjustment, c) minor stoppages, d) reduce speed, e) defect dan f) reduced yield. Tester status lengkap dapat dilihat pada gambar 3 dibawah.

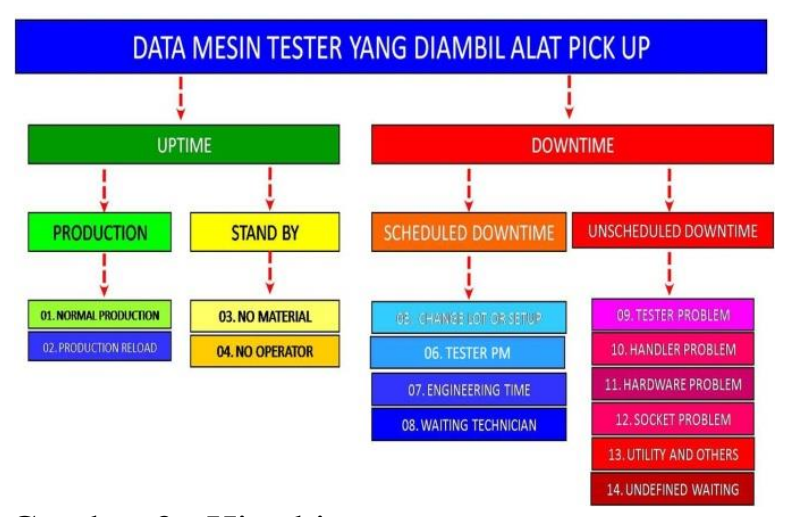

Gambar 3.. Hirarki status tester

\subsection{Analisa Kebutuhan Proses.}

Kebutuhan proses dari sistem informasi yang dirancang meliputi ;

1. Proses penampilan proses produksi secara real time, yaitu penampilkan gambaran proses produksi pada client computer secara visual yang menggambarkan status proses produksi yang sedang berlangsung.

2. Proses pembuatan laporan kinerja equipment, yaitu proses pembuatan laporan kinerja mesin yang ditinjau dari pergantian waktu dalam rentang waktu yang dinginkan.

3. Proses penelusuran status equipment, yaitu proses menelusuri setiap status equipment yang telah dialami equipment dalam rentang waktu yang diinginkan.

4. Proses alert e-mail untuk tester yang down lebih dari 3 jam, yaitu proses pengiriman email kepada bagian-bagian yang berkepentingan terhadap kinerja produksi khususnya berkaitan dengan kerusakan mesin.

\subsection{Analisa Kebutuhan Data/database}

Data yang dikelolah dalam sistem informasi manufaktur OEE yaitu ;

1) Data proses produksi berupa a) departemen, b)work group (shift), c)tester, d)handler, e)operator, f)handler type, g)tester type, h)transaksi, i)tester status, j)device, k)loadboard, 1)test program m)lot, n)package, o)customer dan socket.

2) Data tester status yang dipilih oleh operator atau data yang dideteksi oleh program otomasi akuisisi data.

\subsection{Analisa Kebutuhan Input}

Kebutuhan input didapat dari proses akuisisi data otomatis yang diambil dari data proses produksi yang terdapat dalam file rufus.txt dan pemilihan status tester oleh operator didalam program di tester computer serta pendeteksian aktifitas tester oleh program akuisisi data.

\subsection{Analisa Kebutuhan Output}

Kebutuhan output dari masing-masing komponen adalah sebagai berikut;

1. Karyawan PT. ABC, meliputi informasi proses produksi berupa real time view, informasi kinerja machine/equipment dan informasi tracking tester status.

2. Test Management meliputi informasi proses produksi berupa real time view, informasi kinerja machine/equipment, informasi tracking tester status dan e-mail alert untuk mesin yang down lebih dari 3 jam. 
3. Test Equipment meliputi informasi proses produksi berupa real time view, informasi kinerja machinelequipment, informasi tracking tester status dan e-mail alert untuk mesin yang down lebih dari 3 jam.

4. Test Engineering meliputi informasi proses produksi berupa real time view, informasi kinerja machine/equipment, informasi tracking tester status dan e-mail alert untuk mesin yang down lebih dari 3 jam.

5. Test manufakturing meliputi informasi proses produksi berupa real time view, informasi kinerja machine/equipment, informasi tracking tester status dan $e$-mail alert untuk mesin yang down lebih dari 3 jam.

\section{PERANCANGAN SISTEM DAN PENGEMBANGAN APPLIKASI}

\subsection{Desain Sistem (User Design)}

6.1.1 Desain Proses (Process modeling)

Desain proses dilakukan dengan menggunakan tool DFD.

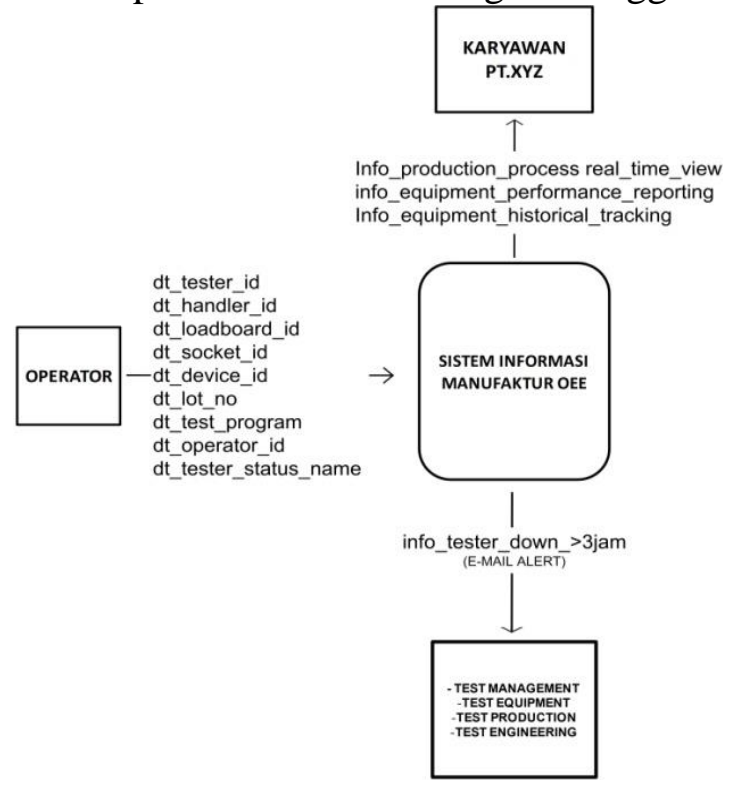

Gambar 4. Konteks diagram

\subsubsection{Dekomposisi (decomposition)}

Dekomposisi (decomposition) sistem yang akan dibangun berdasarkan kebutuhan menghasilkan 5 proses yaitu proses akuisisi data, production process real time view, equipment performance reporting, equipment historical tracking dan e-mail alert untuk sistem yang down lebih dari 3 jam. Detail proses sebagai berikut :

a. Akuisisi data merupakan proses pengambilan data secara otomatis yang dilakukan oleh program sekaligus menjadi input sistem. Data proses produksi diambil dari file rufus.txt dan tester_data.txt, selanjutnya disimpan di CIM server sebagai transaksi.

b. production process real time view merupakan proses penampilan gambaran proses produksi dalam bentuk gambar dengan warna tertentu yang mengindentifikasikan status tester dan informasi proses produksi.

c. equipment performance reporting merupakan proses pembuatan laporan kinerja equipment berdasarkan rentang waktu yang telah dilalui.

d. equipment historical tracking merupakan proses penelusuran status setiap tester yang telah dilalui. 
e. e-mail alert merupakan proses pengiriman e-mail alert ke bagian-bagian yang berkepentingan terhadap kondisi equipment yaitu test management, test production, test equipment dan test engineering.

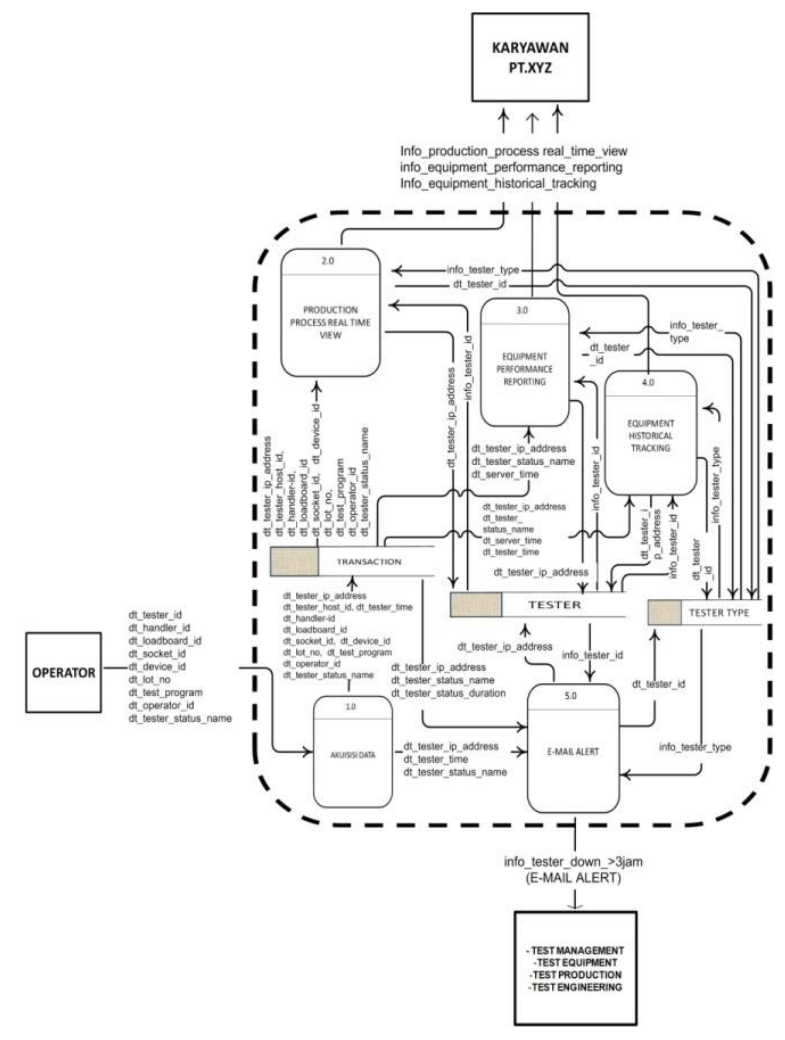

Gambar 5. DFD level 0

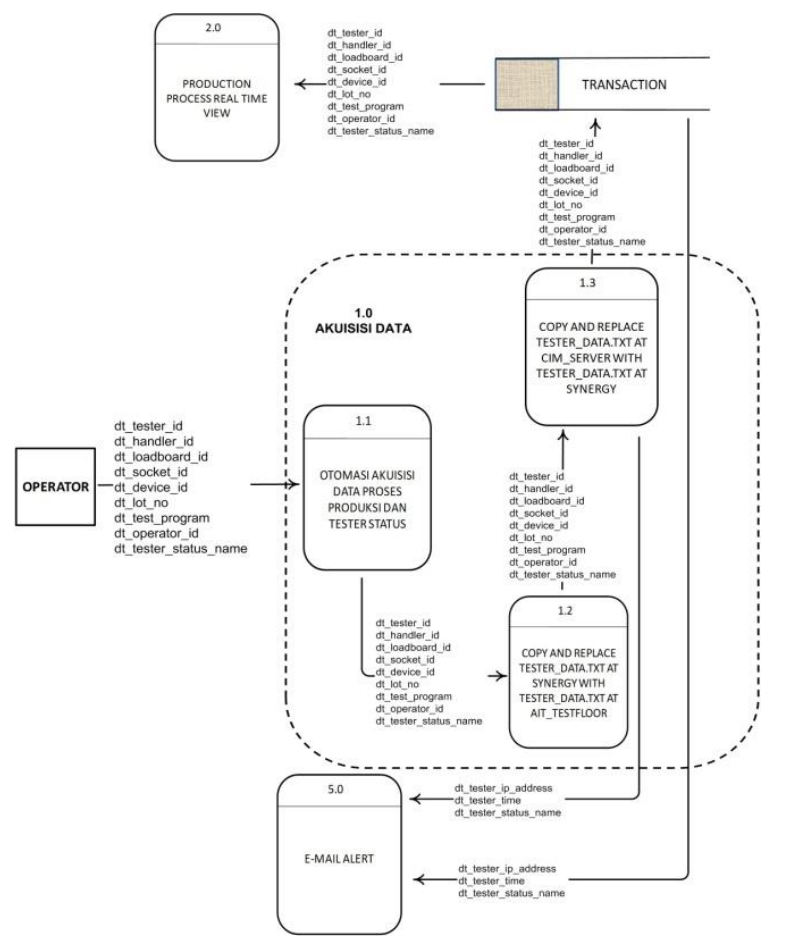


Gambar 7. DFD level 1 proses akuisisi

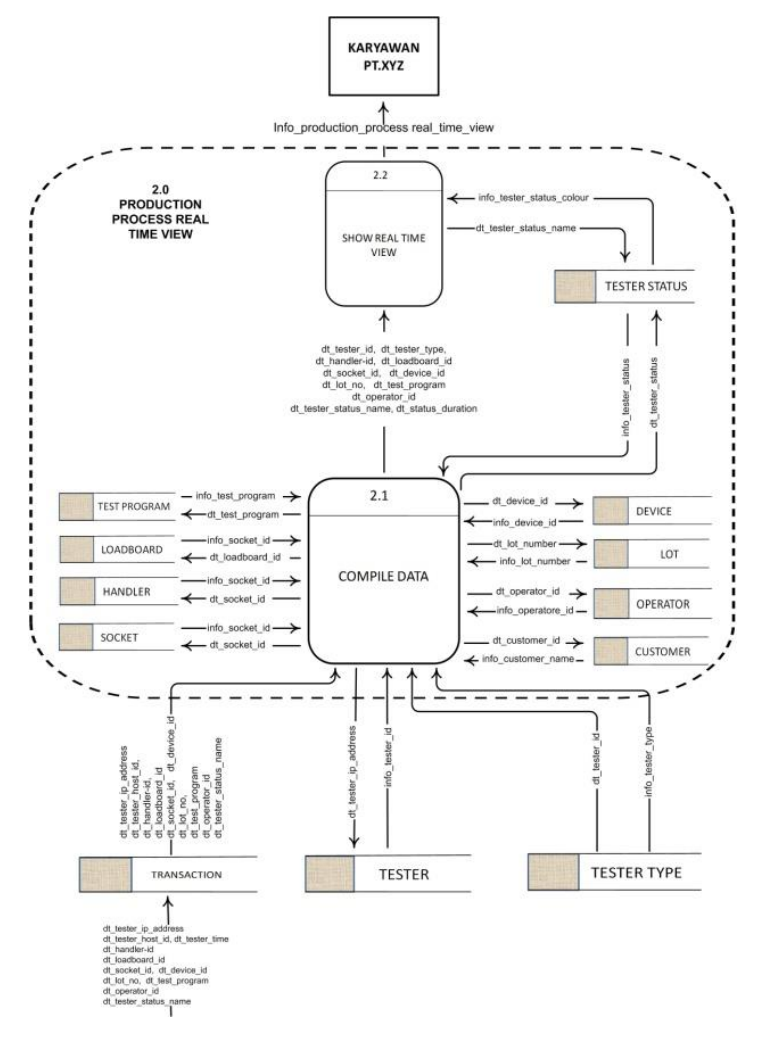

Gambar 8. DFD level 1 proses production process real time view 


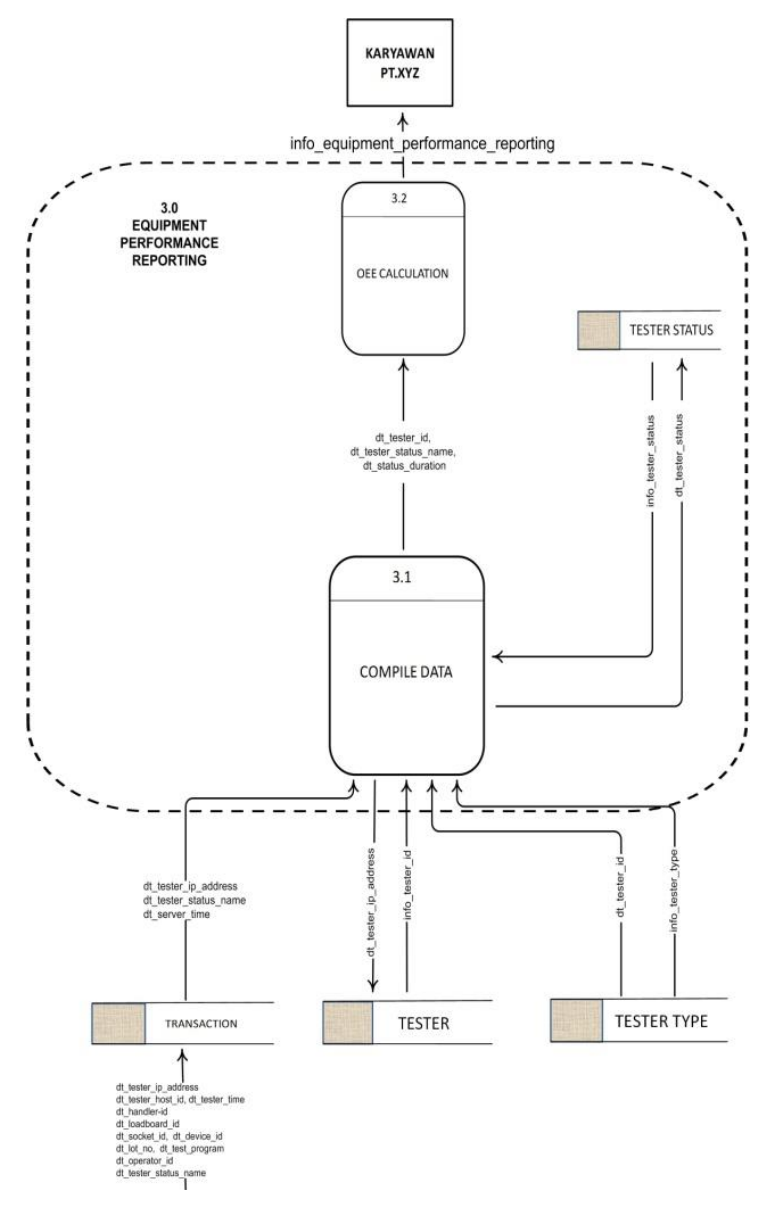

Gambar 9. DFD level 1 proses equipment performance reporting

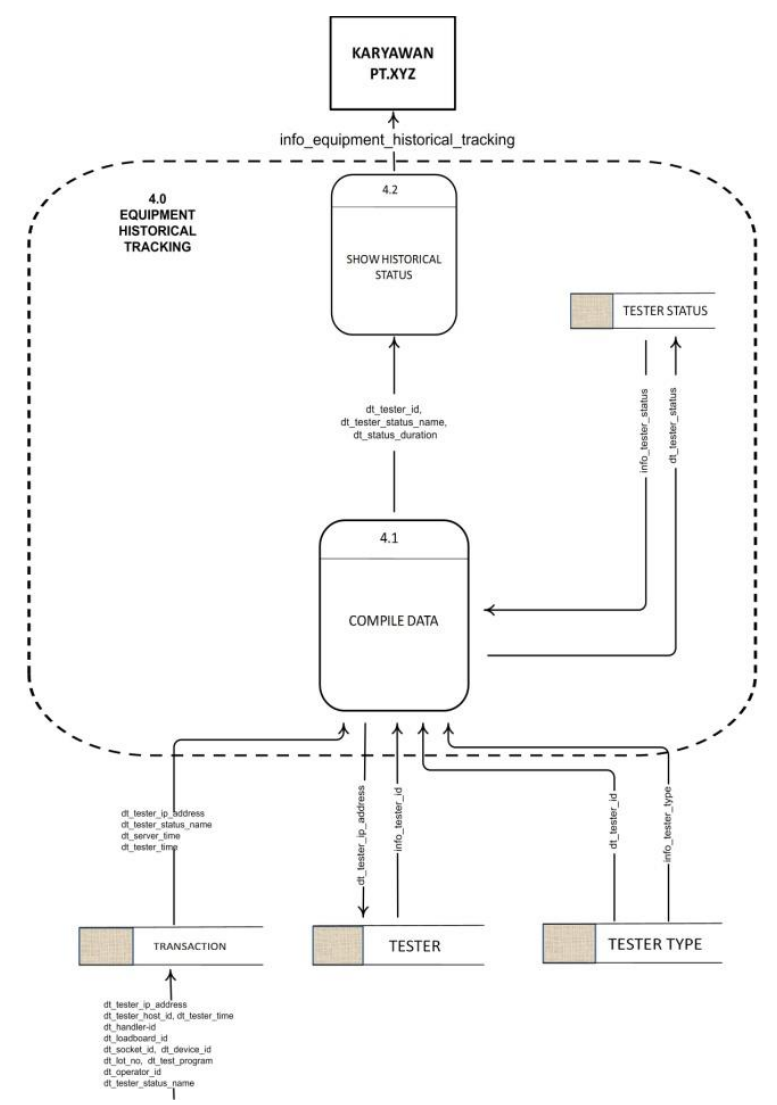


Gambar 11. DFD level 1 proses equipment historical tracking

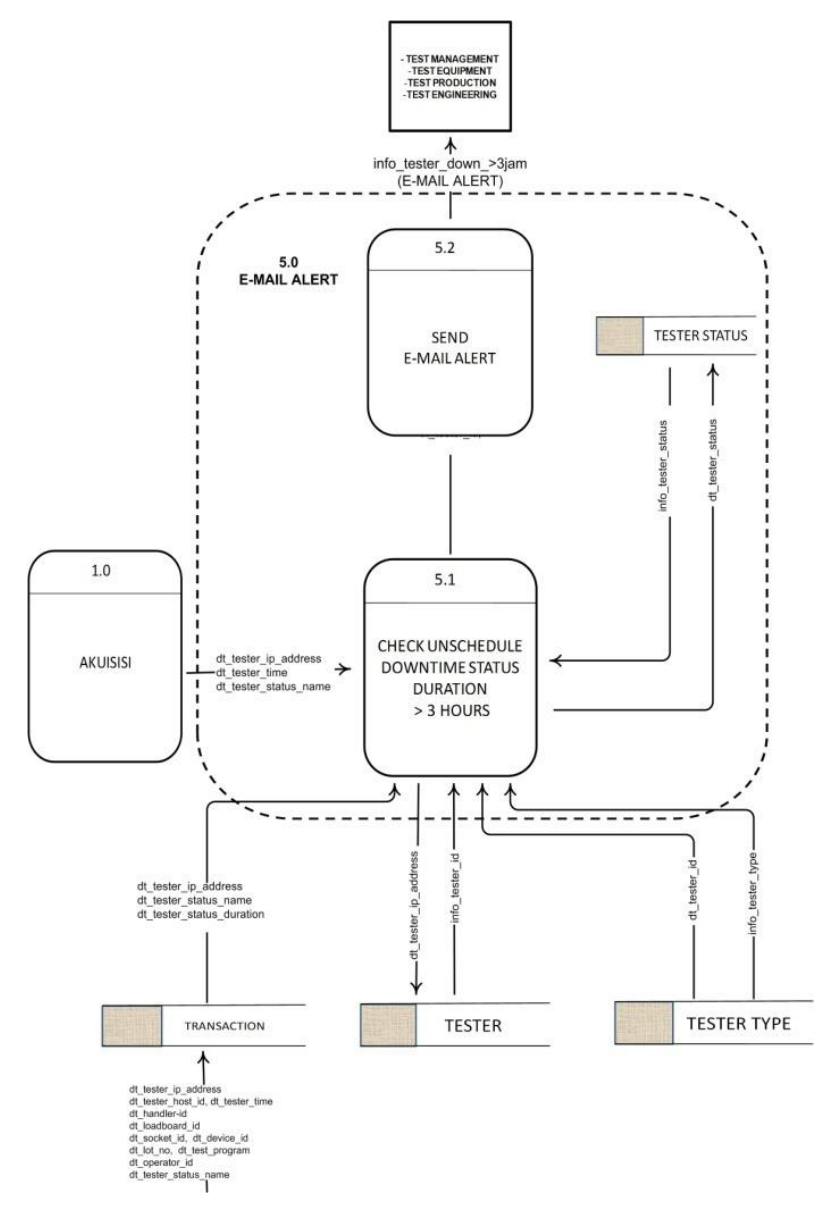

Gambar 12. DFD level 1 proses alert e-mail untuk major downtime

\subsubsection{Desain Database (Pemodelan Data/Data Modelling)}

Desain database dilakukan dengan menggunakan tool ERD. Entity Relationship Diagram (ERD) merupakan notasi grafis dalam pemodelan, ERD digunakan untuk menggambarkan hubungan antar entitas secara konseptual.

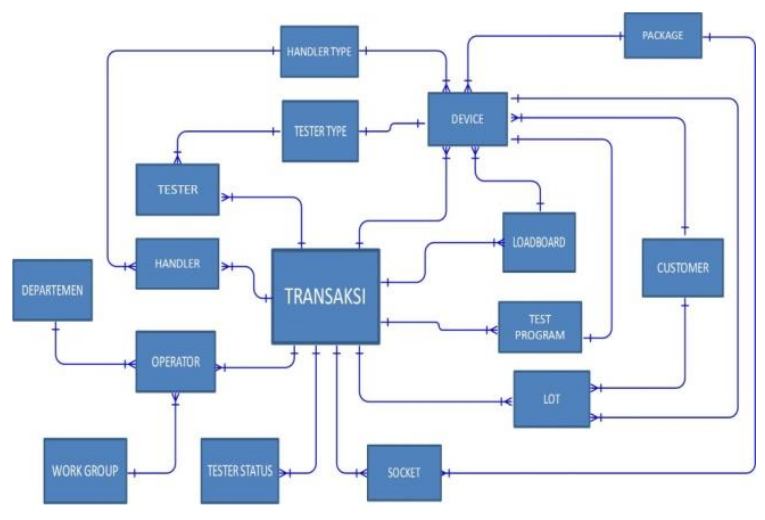

Gambar 13. Hubungan antara entitas

\subsubsection{Desain dan Prototyping Input}


Data input sistem informasi manufaktur OEE diambil dengan membaca data didalam file rufus.txt. File rufus.txt dibuat secara otomatis oleh sistem tester saat operator melakukan proses production data entry,

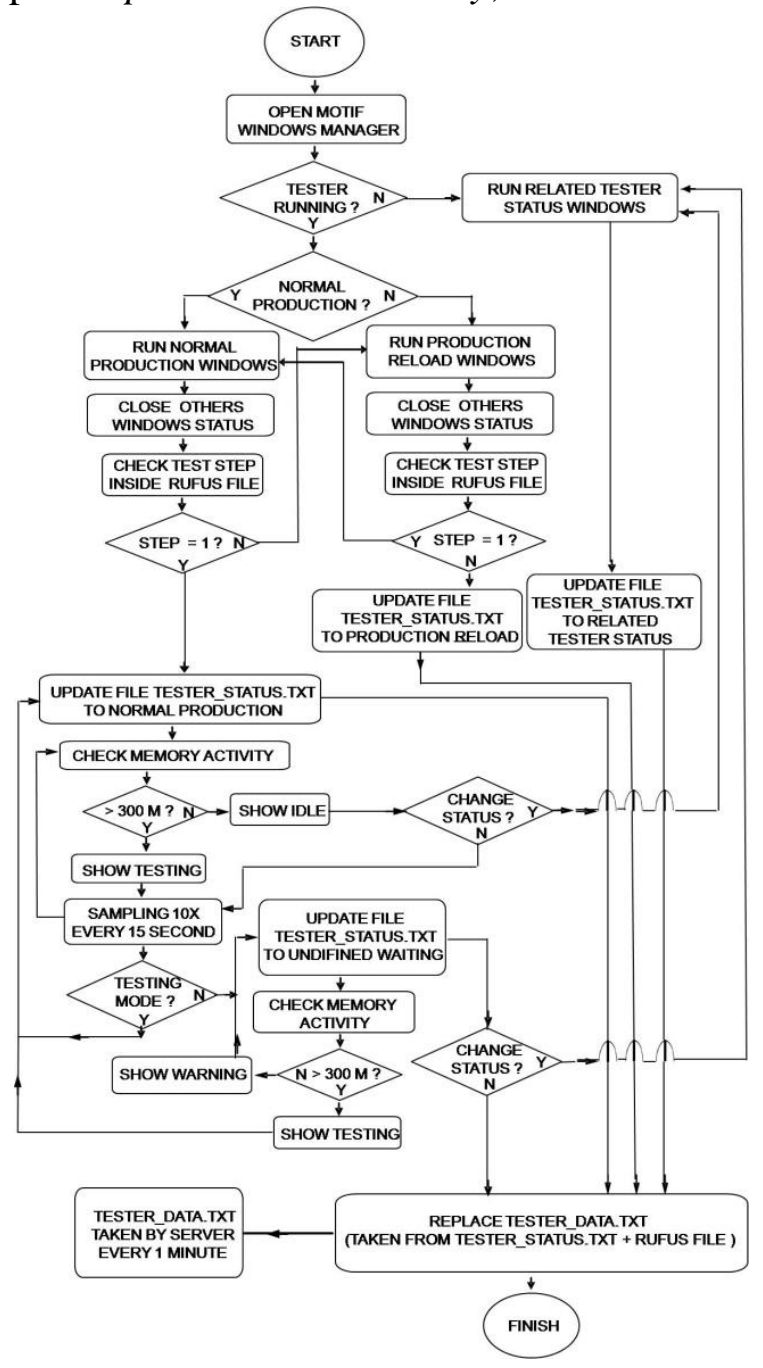

Gambar 14. Flow chart input sistem.

\subsubsection{Desain dan Prototyping Output.}

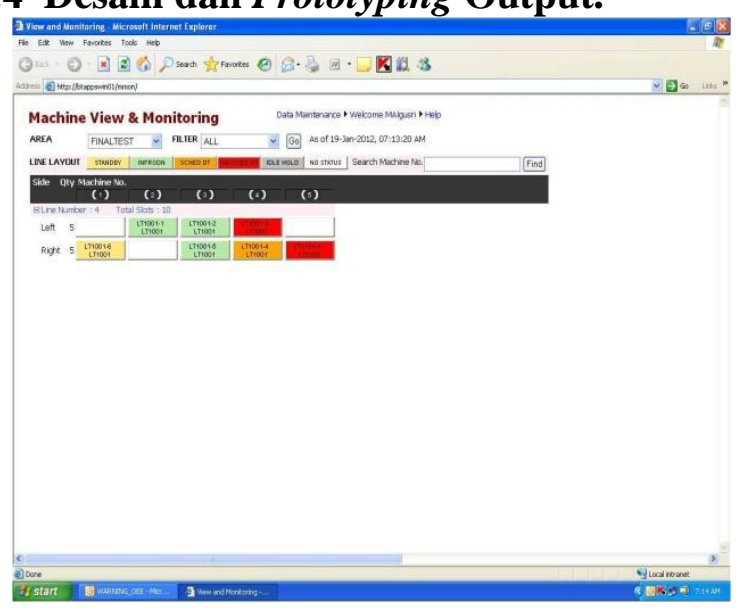

Gambar 15. Prototyping Real time view 


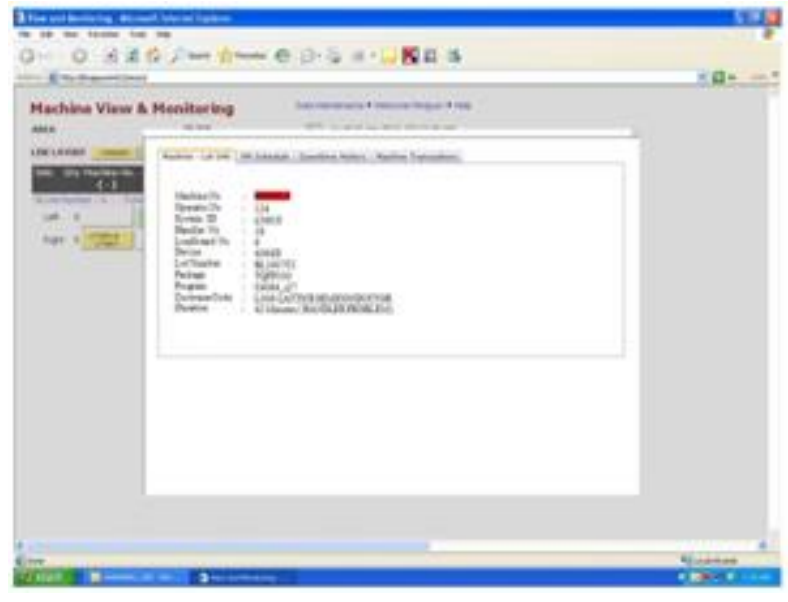

Gambar 16. Real time view dengan detail status dan lot data

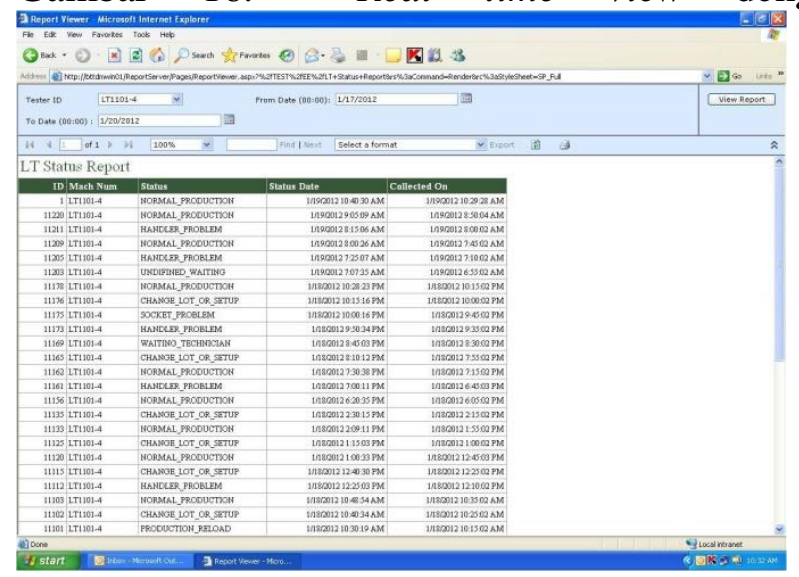

Gambar 17. Equipment state history tracking view

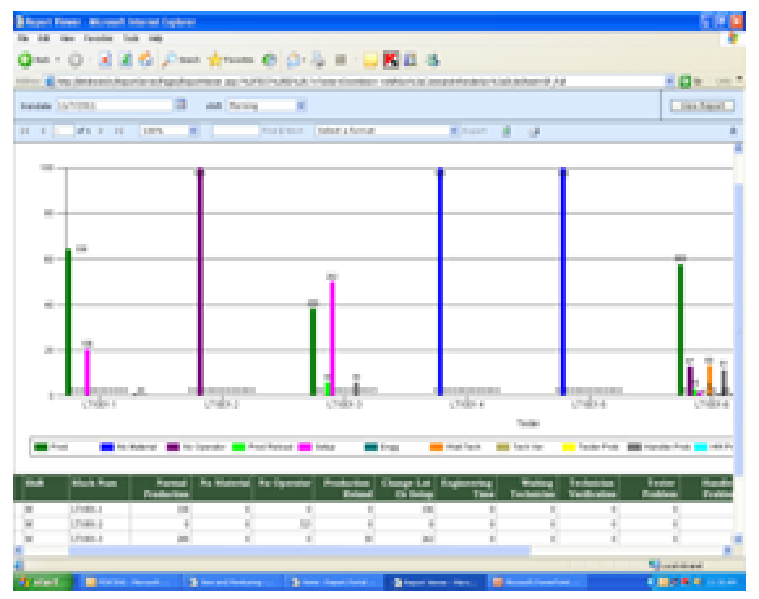


Gambar 18. Shift reporting

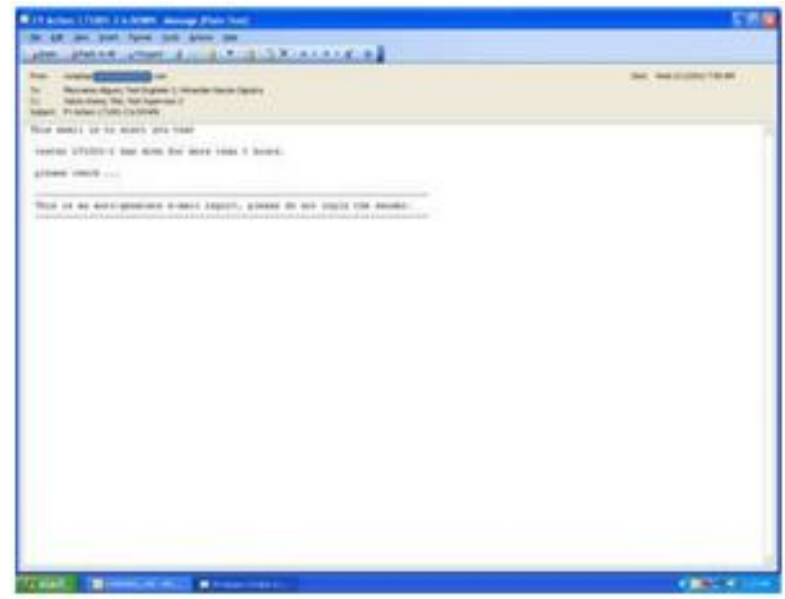

Gambar 19. Alert e-mail untuk equipment yang down lebih dari 3 jam.

\subsubsection{Desain dan Prototyping Interface}

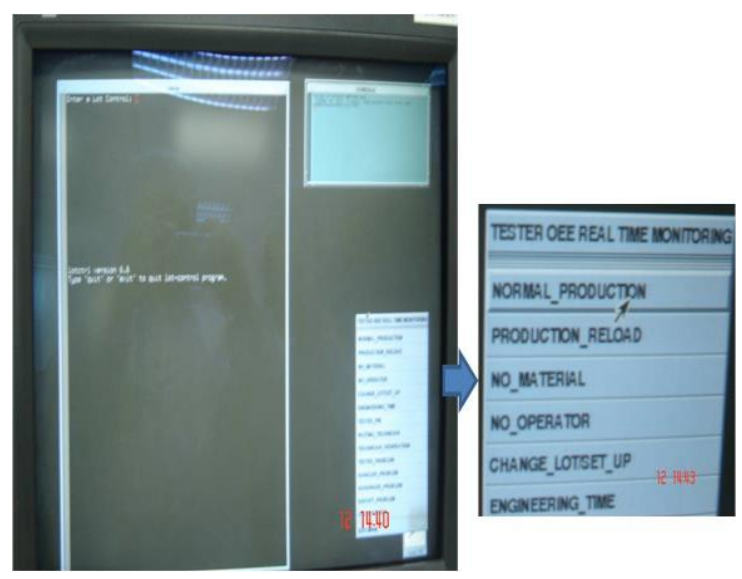

Gambar 20. Environment motif windows manager 


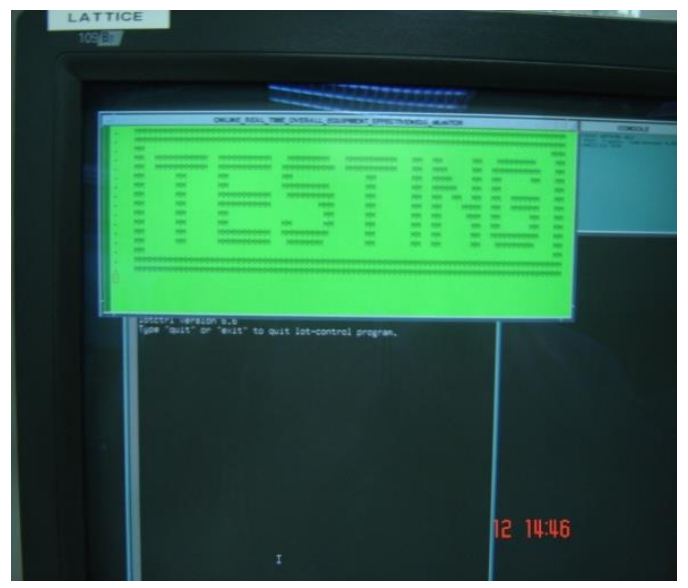

Gambar 21. Sampling mendeteksi testing di tester computer

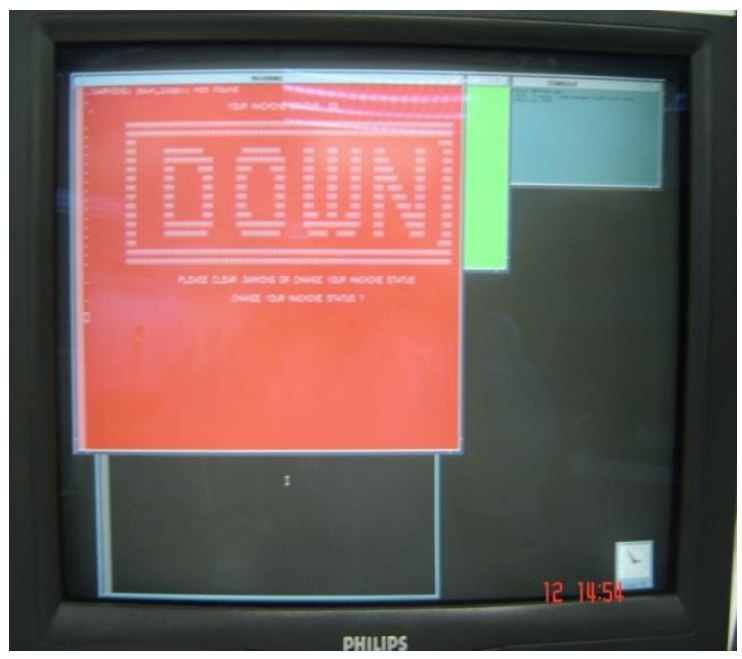

Gambar 22. Warning OEE

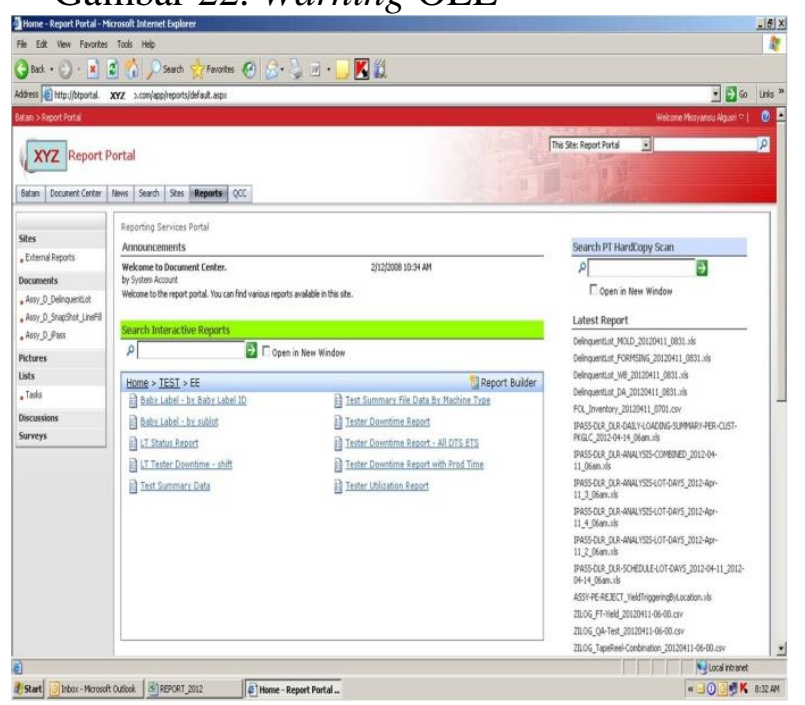

Gambar 23. Tampilan windows equipment tracking dan shiftly reporting 


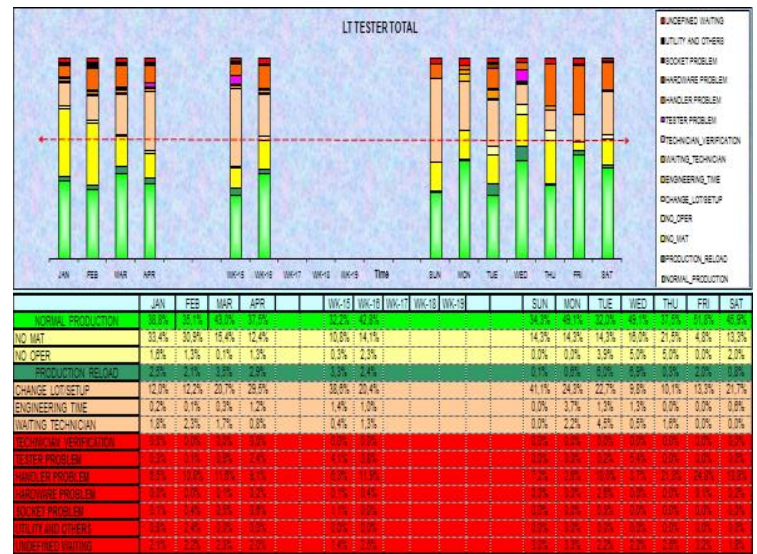

Gambar 24. Manipulasi data reporting lattice cell performance

\subsection{Rapid Construction}

Pembuatan applikasi dilakukan secara paralel antara applikasi di tester computer dan applikasi bagi server dan client computer. Pembuatan applikasi pada tester computer memamfaatkan GUI environment motif window manager, bahasa pemrograman yang digunakan adalah bahasa $\mathrm{C}$ dengan tambahan command-command sistem operasi unix sunOS. Pembuatan applikasi pada server dilakukan dengan menggunakan program visual basic 6 (VB6) dan program applikasi database SQL server sedangkan untuk mengakses dari client computer dapat menggunakan applikasi internet berupa internet explorer, mozilla firefox atau applikasi internet lainnya.

\subsection{Iteration}

Langkah iteration atau proses pengulangan dilakukan untuk memastikan sistem baru yang diapplikasikan ke lantai produksi telah dapat memenuhi kebutuhan dan keinginan pemakai dan management.

\subsection{Evaluasi Sistem}

Evaluasi sistem dilakukan dengan membandingkan keadaan sesudah implementasi dengan keadaan sebelum implementasi. Faktor-faktor yang di bandingan sesuai dengan PIECES yaitu performance, informasi, ekonomi, control dan efficiency. Analisa faktor economi dan efficiency tidak dilakukan pada penelitian ini karena sudah dianggap layak untuk ekonomi dan juga sistem dipastikan akan menguntungkan secara ekonomi dan lebih efisien.

\section{DAFTAR PUSTAKA}

1. Anonim, (2011). “ Equipment Productivity Monitoring System " [http://www.mexter.com.my, diakses 1 April 2011 ]

2. Anonim, (2005). "The Fast guide to OEE "Vorne industries inc: Itasca USA

3. Anonim, (2011). "Increased efficiency with smart performance analysis to FabEagle "[http://www.ais-automation.com/, diakses 1 April 2011]

4. Bamber, C,J. Castka, Sharp, J.M. Motara Y(2003), Cross Functional Team Working For Overall Equipment Effectiveness. Journal of Quality in Maintenance Engineering, Vol 9, no 3, 2003 pp.223-238

5. Betrianis dan Suhendra, Robby (2005), Pengukuran Nilai Overall Equipment Effectiveness sebagai Dasar Usaha Perbaikan Proses Manufaktur Pada Lini Produksi (Studi Kasus pada Stamping Production Division Sebuah Industri Otomotif). Jurnal Teknik Industri Vol. 7, No. 2, Desember 2005: pp. 91- 100 
6. Dal, B., 2000. " Overall Equipment Effectiveness as a Measure of Operational Improvement, “. Int'1 Journal of Operations and Production Management, Vol. 20, p. 1491

7. Frost and Sullivan (2005), "Improving Plant Performance: Overall Equipment Effectiveness (OEE)". Texas; Industrial Automation Practice

8. Groover, P Mikell (2005). " Otomasi, Sistem Produksi, dan Computer-Integrated Manufacturing”. Edisi Kedua, Jilid 1. Surabaya : Guna Widya Kertajaya 178

9. Jogiyanto. (2005). “Analisis dan Desain Sistem Informasi: Pendekatan Terstruktur Teori dan Praktek Applikasi Bisnis". Yogyakarta: Andi offset

10. Lungberg.O (1998), “Measurement of overall equipment effectiveness as a basic for TPM activities”. International Journal of operation. And production management1998. 18 (5) 495-507. 